\title{
Prospek Pengembangan Usaha Handline Tuna di Perairan D.I. Yogyakarta: Tinjauan Sumber Daya dan Investasi
}

\section{(The Development Prospect of Tuna Handline Business in the Waters of D.I. Yogyakarta: Resource and Investment Overviews)}

\author{
Mustaruddin $^{1 \star}$, Bambang Murdiyanto', Eko Sri Wiyono1, Jufri Pachri Laitupa²
}

(Diterima November 2020/Disetujui Oktober 2021)

\begin{abstract}
ABSTRAK
Pada tahun 2018, produksi tuna D.I. Yogyakarta mencapai 371,66 ton, di mana sekitar $75-82 \%$ ditangkap menggunakan handline. Dominannya hasil tangkapan tuna ini menyebabkan pengembangan handline menjadi sangat bergantung pada potensi sumber daya tuna. Prospek investasi juga penting karena menjadi acuan investor dalam berinvestasi pada usaha handline tuna. Penelitian ini bertujuan menganalisis potensi sumber daya ikan tuna beserta sebaran fishing ground-nya, dan menganalisis kelayakan investasi usaha handline tuna di perairan D.I. Yogyakarta. Data penelitian ini dianalisis menggunakan model Schaefer, pemetaan menggunakan sistem informasi geografis (SIG), dan analisis kelayakan investasi. Potensi ikan tuna di perairan D.I. Yogyakarta mencapai 628,53 ton/tahun, sedangkan produksi rata-rata 427,32 ton/tahun sehingga masih prospektif untuk dikembangkan. Fishing ground potensial untuk penangkapan tuna dengan handline tersebar di perairan Kabupaten Bantul hingga perairan perbatasan barat Kabupaten Gunung Kidul, serta di perairan timur Kabupaten Gunung Kidul. Handline tuna juga prospektif untuk dikembangkan investasinya di D.I. Yogyakarta. Nilai NPV, IRR, ROI, dan B/C ratio handline tuna sangat baik, yaitu masing-masing Rp. 425.121.064; 36,49\%; 9,36; dan 1,22.
\end{abstract}

Kata kunci: handline tuna, investasi, perairan D.I. Yogykarta, sistem informasi geografi, sumber daya ikan

\section{ABSTRACT}

In 2018, tuna production in D.I. Yogyakarta reached 371.66 tons, of which $75-82 \%$ were captured using the handline. The dominance of the tuna caught has led to the development of the handline that highly dependent on the potential of tuna resources. Investment prospects are also important because they become a reference for investors in investing in the tuna handline busineses. This study aims to analyze the potential of tuna fish resources including the spread of its fishing ground and analyze the feasibility of developing tuna handline buseneses in the waters of D.I. Yogyakarta. The data of this study were analyzed using the Schaefer model, mapping using geographic information system (GIS), and investment feasibility analysis. The potential of tuna fish production in the waters of D.I. Yogyakarta reached 628,53 tons/year, while the average production was 427,32 tons/year, so it is still prospective to be developed. Potential fishing ground for tuna handline was spreaded in the waters of Bantul Regency until the western border waters of Gunung Kidul Regency, and in the eastern waters of Gunung Kidul Regency. The tuna handline was also prospective to be developed its investment in D.I. Yogyakarta. The value of NPV, IRR, ROI, and B/C ratio of tuna handline were very good, i.e., IDR 425,121,064; 36.49\%; 9,36; and 1.22 respectively.

Keywords: fish resource, geographic information system, investment, the waters of D.I. Yogyakarta, tuna handline

\section{PENDAHULUAN}

Dalam Undang-Undang No.45 Tahun 2009 tentang perikanan dinyatakan bahwa pengelolaan sektor perikanan dan kelautan melingkupi semua upaya, termasuk proses yang terintegrasi dalam pengumpulan informasi, analisis, perencanaan, konsultasi, pembuatan keputusan, alokasi sumber daya ikan, dan

1 Departemen Pemanfaatan Sumberdaya Perikanan, Fakultas Perikanan dan IImu Kelautan, Institut Pertanian Bogor, Kampus IPB Darmaga, Bogor 16680

${ }^{2}$ Fakultas Perikanan, Universitas Iqra Buru, JI. Prof. Dr. Abd. Bassalamah, Namlea, Maluku 97571

* Penulis Korespondensi:

Email:mus_m03@yahoo.com implementasi serta penegakan hukum peraturan perundang-undangan di bidang perikanan, yang dilakukan oleh pemerintah atau otoritas lain yang diarahkan untuk mencapai kelangsungan produktivitas sumber daya hayati perairan dan tujuan yang telah disepakati. Pengelolaan sektor perikanan dan kelautan tersebut perlu dioptimalkan, di samping karena potensinya yang melimpah juga sangat banyak masyarakat yang menggantungkan hidup pada perairan laut. Sebagai bagian dari institusi pemerintah, Pemerintah Daerah Istimewa Yogyakarta perlu melakukan upaya-upaya yang dapat mengoptimalkan pengelolaan sektor perikanan dan kelautan tersebut. Dalam visi dan misi pada tahun 2017-2022, Gubernur D.I. Yogyakarta melalui semangat "perjumpaan" 
berkomitmen menjadikan sektor perikanan dan kelautan sebagai pintu gerbang masuknya investasi, dengan basis utama pada usaha perikanan tangkap.

Menurut Batista et al. (2015) dan Partosuwirjo et al. (2008), usaha perikanan tangkap merupakan penentu utama keberhasilan pengelolaan sektor kelautan dan perikanan. Bila usaha perikanan tangkap dikembangkan secara ramah lingkungan sesuai dengan daya dukung potensi ikan di perairan maka pe-ngelolaannya dapat berkelanjutan, dan bahkan terbuka peluang pengembangannya. Hal ini menjadi krusial bagi D.I. Yogyakarta karena wilayah perairannya tidak terlalu luas, sementara banyak kegiatan ekonomi yang bergantung pada wilayah perairan. Usaha perikanan tangkap masuk ke dalam kelompok prioritas pengembangan di D.I. Yogyakarta karena banyak memasok kebutuhan pasar, usaha industri kecil dan menengah, serta banyak masyarakat pesisir yang berprofesi sebagai nelayan (Rahmi et al. 2013). Handline dapat dipertimbangkan menjadi opsi pengembangan tersebut karena dapat menangkap ikan unggulan dari jenis tuna dan dapat dioperasikan pada perairan yang lebih jauh dibandingkan dengan kebanyakan usaha perikanan tangkap lainnya di D.I. Yogyakarta. Hal ini bersesuaian dengan arahan Kepmen KP No. 107 tahun 2015 yang menekankan kolaborasi pelaku usaha, industri, masyarakat, dan pemerintah dalam pemanfaatan potensi tuna di perairan yang luas.

DKP (2019) menyatakan bahwa produksi tuna pada tahun 2018 mencapai 371,66 ton, dan rata-rata dalam 7 tahun terakhir (2012-2018) sekitar 427,32 ton/tahun. Dari jumlah tersebut, sekitar 75-82\% ditangkap menggunakan handline. Hal ini memberi penegasan bahwa handline merupakan penghasil utama ikan tuna yang didaratkan nelayan di sepanjang pantai D.I. Yogyakarta. Dominannya hasil tangkapan tuna tersebut menyebabkan pengembangan usaha handline tuna ke depan sangat bergantung pada potensi/stok sumber daya tuna di perairan D.I. Yogyakarta. Informasi potensi tuna penting untuk memastikan keberlangsungan produktivitas hayatinya seba-gaimana yang diamanatkan Undang-Undang No.45 Tahun 2009. Informasi prospek investasi juga penting karena menjadi acuan investor dalam berinvestasi pada usaha handline tuna. Menurut Macusi et al. (2015) dan Prabowo et al. (2013), informasi yang lengkap dan akurat terkait objek investasi akan memudahkan daerah untuk mencari calon investor yang potensial.

Terkait dengan itu, maka dirasa perlu untuk dilakukan kajian terkait prospek pengembangan usaha handline tuna di perairan D.I. Yogyakarta dalam tinjauan sumber daya dan investasi. Penelitian ini bertujuan menganalisis potensi sumber daya ikan tuna beserta sebaran fishing ground-nya, dan menentukan kelayakan investasi usaha handline tuna di perairan D.I. Yogyakarta.

\section{METODE PENELITIAN}

\section{Waktu dan Tempat}

Penelitian ini dilaksanakan pada bulan Agustus 2017-Januari 2018 dan Februari 2019. Tempat penelitian ini adalah D.I. Yogyakarta, dengan lokasi survei di kawasan Pangkalan Pendaratan Ikan (PPI) Pandasimo dan Pelabuhan Perikanan Pantai (PPP) Sadeng.

\section{Jenis Data dan Metode Pengambilan Data}

Data yang dikumpulkan dalam penelitian ini terbagi dalam tiga kelompok, yaitu a) data sumber daya ikan tuna yang mencakup jenis tuna yang didaratkan, produksi ikan tuna, upaya penangkapan, dan peraturan penangkapan tuna; b) data fishing ground ikan tuna yang mencakup data klorofil, suhu permukaan laut (SPL), titik koordinat penangkapan tuna, informasi rumpon, dan musim; dan c) data kelayakan investasi handline tuna yang mencakup kebutuhan investasi, kebutuhan operasional, jumlah anak buah kapal (ABK), ukuran kapal, umur teknis, dan sumber pemodalan.

Data jenis tuna yang didaratkan, titik koordinat penangkapan tuna, informasi umpon, musim, serta data kelayakan usaha handline tuna dikumpulkan dengan teknik wawancara dan pengamatan langsung. Responden wawancara adalah nakhoda/nelayan pemilik yang dipilih secara purposive sekitar $5 \%$ dari populasi nelayan handline tuna di lokasi. Khusus titik koordinat dan informasi rumpon diambil dari 3 nakhoda dari tiap pelabuhan. Pengamatan langsung dilakukan untuk mengumpulkan data yang bersifat dokumentatif dan kroscek atas informasi yang tidak dapat diberikan secara lengkap oleh responden. Data klorofil dan suhu permukaan laut (SPL) diperoleh dengan cara mengunduh data citra satelit Aqua MODIS. Data produksi ikan tuna, upaya penangkapan, dan peraturan terkait dikumpulkan melalui telaah pustaka atas laporan pendaratan ikan di pelabuhan perikanan, buku statistik perikanan tangkap, undang-undang perikanan, keputusan menteri terkait perikanan tuna, serta hasilhasil kajian yang tersedia di DKP D.I. Yogyakarta, lembaga riset, dan perguruan tinggi.

\section{Analisis Data}

Data penelitian ini dianalisis menggunakan model Schaefer, aplikasi GIS, dan analisis kelayakan investasi. Model Schaefer digunakan untuk menghitung potensi lestari (maximum sustainable yield/MSY) ikan tuna di perairan D.I. Yogyakarta. Terkait dengan keadaan ini maka jenis ikan tuna yang didaratkan, jumlah produksi/hasil tangkapan ikan tuna, dan upaya penangkapan menjadi informasi penting dalam analisis ini. Dari data tersebut kemudian dibuat model regresi terkait hubungan jumlah hasil tangkapan per satuan upaya yang telah distandardisasi (c/f) 
dengan upaya penangkapan yang telah distandardisasi (f). Nilai konstanta (b) dan intercept (a) pada model regresi linear, selanjutnya digunakan dalam perhitungan:

$$
\begin{aligned}
\text { MSY } & =a\left(\frac{a}{2 b}\right)-b\left(\frac{a^{2}}{4 b^{2}}\right) \\
T P & =\left(\frac{c_{i}}{M S Y}\right) \times 100 \%
\end{aligned}
$$

Keterangan:

$$
\begin{array}{ll}
\text { MSY } & =\text { Potensi lestari tuna } \\
\text { TP } & =\text { Tingkat pemanfaatan tuna } \\
\mathrm{C}_{i} & =\text { Jumlah hasil tangkapan riil tuna }
\end{array}
$$

Aplikasi GIS digunakan untuk mengestimasi fishing ground ikan tuna ke dalam ilustrasi peta. Untuk mendapatkan akurasi yang tinggi maka data klorofil dan suhu permukaan laut (SPL) yang didapat dari citra satelit dikroscek dengan informasi nelayan terkait titik koordinat mereka menangkap ikan tuna dan posisi rumpon di perairan D.I. Yogyakarta. Di samping itu, pola musim juga dipertimbangkan untuk melihat sebaran klorofil dan suhu permukaan laut (SPL).

Analisis investasi digunakan untuk menentukan kelayakan pengembangan handline tuna di perairan D.I Yogyakarta. Hal ini dilakukan bila tingkat pemanfaatan tuna di perairan D.I Yogyakarta masih di bawah potensi lestarinya. Menurut Sumaila et al. (2016) dan Hanley \& Spash (1993), ketertarikan investor untuk mengembangkan suatu usaha perikanan tangkap sangat bergantung pada ketersediaan potensi ikan dan kinerja investasinya. Dalam penelitian ini, parameter analisis yang digunakan untuk menentukan kelayakan investasi handline tuna mengacu pada Mayes \& Shank (2006) dan Hanley \& Spash (1993), yaitu Net Present Value (NPV), Internal Rate Return (IRR), Return of Investment (ROI), dan Benefit-Cost
Ratio (B/C Ratio). Suku bunga yang digunakan dalam analisis mengacu pada suku bunga kredit menurut Bank Indonesia (2017), yaitu 12\%.

\section{HASIL DAN PEMBAHASAN}

\section{Produksi dan Potensi Ikan Tuna}

Jenis ikan tuna yang banyak ditangkap nelayan di D.I. Yogyarakta adalah madidihang, albacore, dan tuna mata besar. Madidihang merupakan jenis terbanyak ditangkap yang mencapai $72-85 \%$ dari total produksi ikan tuna di D.I. Yogyakarta. Akan tetapi, semua jenis tuna diunggulkan dan menjadi fokus pengembangan perikanan tangkap di D.I. Yogyakarta (BAPPEDA 2019). Gambar 1 menyajikan trend produksi ikan tuna di perairan D.I. Yogyakarta selama periode tahun 2012 hingga tahun 2018. Produksi ikan tuna di perairan D.I. Yogyakarta cukup berfluktuasi dari tahun ke tahun (pola polinomial ordo 5 dalam 7 tahun). Pada tahun 2012, produksi ikan tuna mencapai 419,2 ton. Kemudian mengalami peningkatan pada tahun 2013 mencapai 500,6 ton. Lalu menurun cukup tajam pada tahun 2016 dan naik lagi pada tahun 2017.

Ikan tuna yang didaratkan di D.I. Yogyakarta umumnya ditangkap menggunakan handline. Menurut DKP (2018) dan Partosuwirjo et al. (2008), handline banyak digunakan nelayan D.I. Yogyakarta karena dioperasikan dengan kapal ukuran yang cukup besar (>5 GT) dan dapat menjangkau perairan yang lebih jauh. Alat tangkap lain yang digunakan adalah gillnet hanyut dan gillnet tetap, namun tidak banyak dan hanya dioperasikan di perairan terdekat. Gambar 2 menyajikan hasil analisis potensi lestari ikan tuna di perairan D.I. Yogyakarta.

Berdasarkan Gambar 2, potensi produksi ikan tuna di perairan D.I. Yogyakarta mencapai 628,53 ton/tahun. Bila dibandingkan dengan produksi rata-rata pada saat ini $(427,32$ ton/tahun) maka tingkat

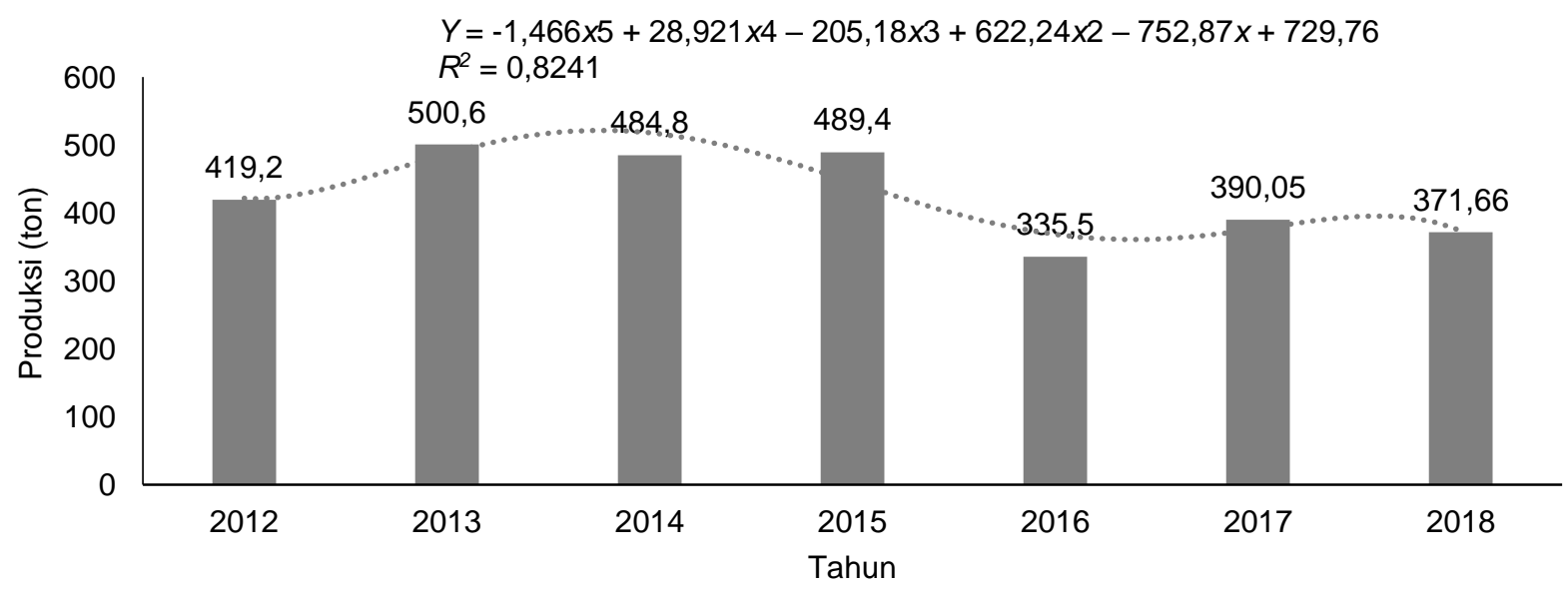

Gambar 1 Produksi ikan tuna di perairan Daerah Istimewa Yogyakarta 


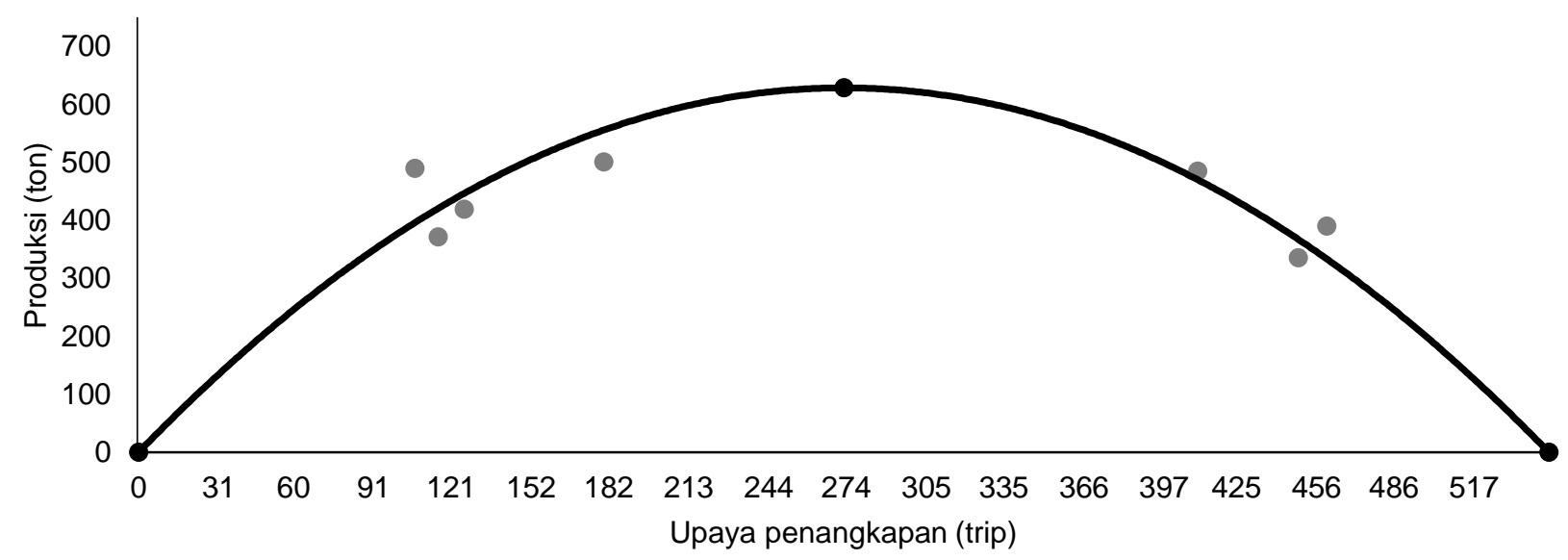

Gambar 2 Potensi ikan tuna di perairan Daerah Istimewa Yogyakarta

pemanfaatannya mencapai $67,99 \%$ (belum melebihi JTB). Artinya, penangkapan sumber daya ikan tuna di perairan D.I Yogyakarta masih berpeluang untuk dikembangkan. Kalaupun banyak hasil tangkapan tuna yang masuk kategori illegal size di perairan D.I. Yogyakarta (Nurani et. al. 2018), diduga lebih karena pilihan alat tangkap dan teknik operasi yang belum tepat, bukan karena potensi tuna yang kritis. Mustaruddin \& Asnil (2020) dan Gephart et al. (2017) menyatakan bahwa pengembangan kegiatan penangkapan ikan dapat dilakukan selama tidak mengganggu kemampuan kritis ikan untuk pulih. Sementara itu, menurut Kepmen KP No 107 tahun 2015, hak untuk menangkap ikan harus disertai dengan kewajiban melakukan kegiatan penangkapan ikan dengan caracara yang bertanggung jawab untuk memastikan efektivitas pelaksanaan tindakan konservasi dan pengelolaan potensi sumber daya ikan.

Terlepas dari itu, penangkapan suatu jenis ikan seyogyanya tidak dilakukan pada nilai kritis potensi, tetapi harus dikurangi untuk mengantisipasi pengaruh faktor lingkungan yang sulit diprediksi. Faktor lingkungan yang dimaksud di antaranya el nino, la nino, dan destruksi pada rantai makanan di perairan. Faktor lingkungan memengaruhi sebaran suhu air laut, komponen nutrien (klorofil), yang kemudian diikuti dengan pola migrasi, pertumbuhan, dan perkembangan ikan. Menurut Mustaruddin et al. (2018) dan Macusi et al. (2015), pengaruh tersebut dapat diidentifikasi dari perubahan fishing ground suatu jenis ikan selama periode tertentu. Bagian berikut menyajikan hasil analisis fishing groud ikan tuna di perairan D.I. Yogyakarta.

\section{Fishing Ground Ikan Tuna}

Bagi usaha handline tuna, fishing ground merupakan wilayah perairan di mana handline dapat dioperasikan dengan efektif karena banyak terdapat sumber daya ikan tuna. Menurut Jalali et al. (2015) dan Mustaruddin et al. (2018), pada fishing ground ini, ikan sasaran dapat tertangkap dengan mudah, dan kegiatan operasi penangkapan mendapat keuntungan ekonomis. Beberapa tempat di perairan D.I. Yogyakarta dapat menjadi fishing ground bila banyak ikan tuna yang berkumpul dan handline atau tangkap lainnya yang sesuai bisa dioperasikan. Sementara itu, penyebab ikan berkumpul di suatu wilayah perairan, di antaranya adalah utuk mencari makanan, mencari tempat memijah maupun berkembang biak, serta karakteristik perairan tersebut cocok untuk kehidupan suatu jenis ikan (Punzon et al. 2004).

Menurut Coelho et al. (2015) dan Jalali et al. (2015), pengumpulan ikan pelagis besar (termasuk ikan tuna) mudah ditemukan bila kesuburan perairan sekitarnya sangat tinggi (klorofil-a $>0,2 \mathrm{mg} / \mathrm{m}^{3}$ ). Hasil analisis citra satelit menunjukkan bahwa klorofil-a $>0,2 \mathrm{mg} / \mathrm{m}^{3}$ terjadi: (a) di perairan Kabupaten Bantul hingga perairan barat Kabupaten Gunung Kidul (110'16'26" BT dan $110^{\circ} 29^{\prime} 25^{\prime \prime} \mathrm{BT}$ ) dengan sebaran tertinggi pada bulan April, dan (b) di sepanjang pantai D.I. Yogyakarta dengan sebaran tertinggi pada bulan Mei dan Januari. Meskipun klorofil-a tinggi, ikan tuna tidak akan mengumpul secara maksimal bila suhu permukaan laut (SPL) tidak sesuai. Ikan tuna menyukai perairan dengan suhu sedang, berkisar $27-29,3^{\circ} \mathrm{C}$ (Jalali et al. 2015, Macusi et al. 2015, dan Simbolon et al. 2009). SPL seperti ini banyak terjadi: (a) di perairan timur Kabupaten Gunung Kidul, dan (b) di perairan Kabupaten Bantul hingga perairan perbatasan barat Kabupaten Gunung Kidul. SPL sedang di tiga wilayah perairan ini umumnya terjadi di kisaran lintang $8^{\circ} 19^{\prime} 30^{\prime \prime}$ LS dan $8^{\circ} 39^{\prime} 40^{\prime \prime}$ LS.

Mengacu pada metode analisis, data klorofil dan SPL tersebut perlu dikroscek dengan informasi/ pengalaman nelayan melaut untuk mendapatkan hasil estimasi fishing ground yang lebih akurat. Dari survei yang dilakukan, nelayan handline di D.I. Yogyakarta umumnya menangkap tuna pada lokasi yang cukup jauh dari pantai dan menggunakan kapal handline di atas 5 GT. Tabel 1 menyajikan informasi tentang titik koordinat penangkapan tuna tersebut di perairan D.I. Yogyakarta dan keberadaan rumpon di sekitarnya.

Pada musim timur (Mei-Juli), SPL dan klorofil-a berada pada kondisi yang paling ideal untuk ikan tuna, 
yaitu SPL sedang dan klorofil-a umumnya tinggi (ratarata $\left.0,839681 \mathrm{mg} / \mathrm{m}^{3}\right)$. SPL dan klorofil seperti itu umumnya terjadi pada perairan yang cukup luas antara $8^{\circ} 18^{\prime} 37^{\prime \prime}$ LS dan $8^{\circ} 45^{\prime} 40^{\prime \prime}$ LS serta antara $110^{\circ} 06^{\prime} 32^{\prime \prime}$ BT dan $110^{\circ} 45^{\prime} 16^{\prime \prime}$ BT. Angin laut juga tidak terlalu kencang di perairan tersebut sehingga banyak nelayan handline dari PPI Pandasimo dan PPP Sadeng melakukan operasi penangkapan tuna di sana ketika musim timur tiba. DKP (2018) dan Partosuwirjo et al. (2008) menyatakan ketika musim timur terjadi, permintaan perbekalan meningkat $65-90 \%$ di PPI Pandasimo dan PPP Sadeng untuk memenuhi kebutuhan kapal-kapal handline yang berangkat melaut.

Dengan memperhatikan informasi klorofil-a, SPL, pengalaman nelayan, dan informasi musim maka dapat disusun peta sebaran fishing ground ikan tuna di perairan D.I. Yogyakarta seperti pada Gambar 3. Informasi-informasi tersebut saling melengkapi satu sama lain dan peririsannya memperkuat penetapan spot fishing ground di peta tersebut.

Berdasarkan Gambar 3, fishing ground ikan tuna umumnya tersebar di perairan Kabupaten Bantul hingga perairan perbatasan barat Kabupaten Gunung Kidul, serta di perairan timur Kabupaten Gunung Kidul. Fishing ground tersebut agak ke tengah, yaitu pada wilayah perairan bersuhu sedang yang disukai oleh ikan tuna. Hasil analisis SPL menunjukkan suhu sedang di perairan timur Kabupaten Gunung Kidul umumnya terjadi pada bulan Mei, Juni, dan Agustus. Pada kisaran bulan tersebut, SPL rata-rata di perairan D.I. Yogyakarta tidak terlalu hangat dan tidak terlalu dingin, yaitu $27,44^{\circ} \mathrm{C}$ pada bulan Mei dan $27,67^{\circ} \mathrm{C}$ pada bulan Juni sehingga sangat cocok untuk pengumpulan ikan tuna. Untuk perairan Kabupaten Bantul dan perairan perbatasan barat Kabupaten Gunung Kidul, SPL sedang terjadi pada bulan April, September, dan Oktober.

Fishing ground ikan tuna tersebut umumnya agak ke tengah dan penyebar pada wilayah yang luas. Hal ini dominan dipengaruhi oleh pola migrasi ikan-ikan kecil yang menjadi mangsa, yaitu bergerak dinamis menuju/dari perairan yang lebih subur (berklorofil-a tinggi) di sekitaran pantai. Pada kondisi ini, ikan tuna menghalaunya dengan menyebar di perairan agak ke tengah. Menurut Doddema et al. (2017) dan Jaquemet et al. (2010), pada wilayah perairan yang menjadi persinggahan dan lalu lintas migrasi ikan-ikan kecil, banyak ditemukan ikan tuna, meskipun kesuburan perairan tersebut biasa-biasa saja. Hal ini relevan dengan penelitian Coelho et al. (2015) yang menyatakan bahwa pergerakan dan pencarian mangsa menjadi faktor utama penyebaran ikan tuna di perairan. Dalam konteks musim, migrasi mangsa ini diduga tinggi pada

Tabel 1 Titik koordinat penangkapan tuna dengan handline dan keberadaan rumpon di sekitarnya

\begin{tabular}{|c|c|c|}
\hline Sumber & Titik koordinat & Keberadaan rumpon \\
\hline Informan 1 & $8^{\circ} 21^{\prime} 22^{\prime \prime}$ LS dan $110^{\circ} 05^{\prime} 27^{\prime \prime}$ BT & Tidak ada informasi \\
\hline Informan 2 & $8^{\circ} 45^{\prime} 31^{\prime \prime}$ LS dan $110^{\circ} 17^{\prime} 15^{\prime \prime}$ BT & Ada \\
\hline Informan 3 & $8^{\circ} 46^{\prime} 32^{\prime \prime}$ LS dan $110^{\circ} 49^{\prime} 25^{\prime \prime}$ BT & Ada \\
\hline Informan 4 & $8^{\circ} 28^{\prime} 11^{\prime \prime}$ LS dan $110^{\circ} 44^{\prime} 05^{\prime \prime}$ BT & Tidak ada informasi \\
\hline Informan 5 & $8^{\circ} 32$ '38" LS dan $110^{\circ} 21^{\prime} 25^{\prime \prime}$ BT & Tidak ada informasi \\
\hline Informan 6 & $8^{\circ} 26^{\prime} 38^{\prime \prime}$ LS dan $110^{\circ} 20^{\prime} 32^{\prime \prime}$ BT & Ada \\
\hline
\end{tabular}

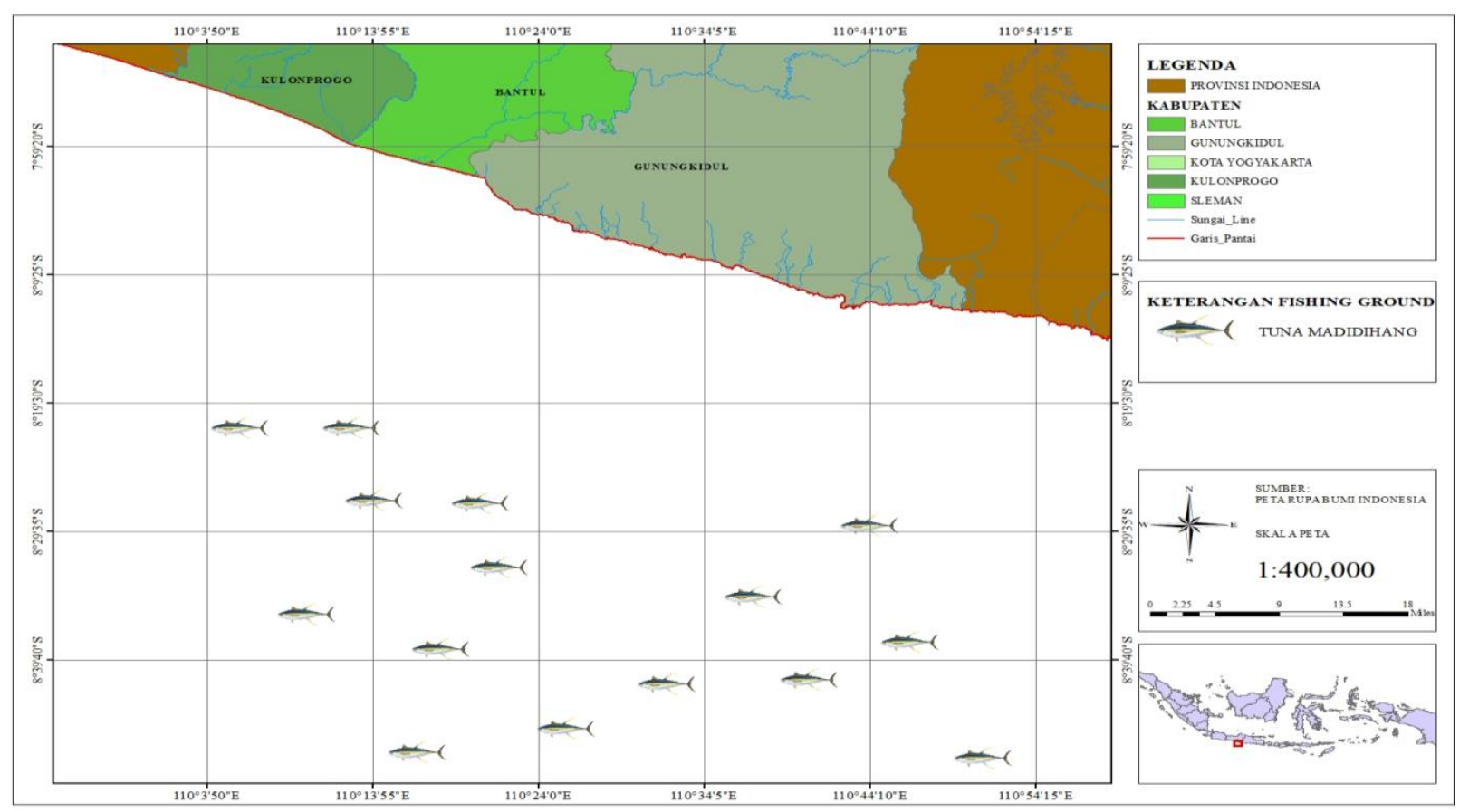

Gambar 3 Peta fishing ground ikan tuna di perairan Daerah Istimewa Yogyakarta 
musim timur karena dari ulasan sebelumnya ikan tuna banyak ditemukan di perairan D.I. Yogyakarta. Faktor cuaca yang lebih bersahabat (angin laut) mengoptimalkan operasi handline pada wilayah perairan yang lebih luas di musim tersebut.

\section{Kelayakan Pengembangan Investasi Handline Tuna}

Informasi potensi sumber daya ikan tuna yang masih terbuka untuk dimanfaatkan, lengkap dengan informasi fishing ground-nya akan memudahkan pengembangan investasi handline tuna. Untuk menjadi acuan bagi investor dalam pengembangan investasi tersebut, maka kebutuhan investasi dan kelayakannya juga perlu ditentukan. Hasil survei lapang menunjukkan bahwa kebutuhan investasi handline tuna terdiri atas kapal motor, alat tangkap pancing (handline), mesin induk, mesin tambahan, GPS, radio, lampu merkuri, cooler box atau wadah-wadah pendukung, serta tangki/drum air (Tabel 2).

Kebutuhan investasi handline tuna termasuk tinggi bila dibandingkan dengan usaha perikanan tangkap lainnya. Hal ini karena skala pengusahaan handline di D.I. Yogyakarta lumayan besar, yaitu menggunakan kapal motor di atas 5 GT dan dioperasikan oleh 4-5 orang. Riandani et al. (2015) dan Partosuwirjo et al. (2008) menyatakan bahwa handline merupakan usaha perikanan tangkap dengan skala pengusahaan paling besar di D.I. Yogyakarta karena ditujukan untuk menangkap ikan di perairan yang cukup jauh. Skala pengusahaannya jauh lebih besar daripada gillnet, trammel net, dan rawai dasar. Hal ini juga yang menyebabkan handline hanya diusahakan di kawasan pelabuhan perikanan yang sarana pendukungnya memadai, seperti PPP Sadeng dan PPI Pandasimo. Sarana pendukung yang vital di antaranya kolam pelabuhan yang cukup luas dan dalam, sumber pasokan BBM, es balok, dan ransum yang cukup. Tabel 3 menyajikan kebutuhan operasional handline tuna di D.I. Yogyakarta.

Berdasarkan Tabel 3, kebutuhan operasional handline tuna mencapai Rp168.489.750/tahun. Komponen operasional terbesar terdiri atas solar (Rp88.920.000/tahun), es balok (Rp27.800.000/tahun), dan ransum (Rp25.350.000/tahun). Meskipun tidak dioperasikan secara aktif (kapal terus bergerak), rasio penggunaan BBM pada handline tuna termasuk banyak karena fishing ground-nya lebih jauh dan operasi penangkapan juga dilakukan di malam hari/menggunakan lampu (Riandani et al. 2015, Macdonald et al. 2009 dan Sanders 1999). Es balok dan ransum juga banyak dibutuhkan, selain karena skala pengusahaan dan jumlah ABK-nya yang relatif besar, juga karena jumlah hari operasinya yang lebih banyak, misalnya bila dibandingkan dengan gillnet atau rawai dasar.

Handline tuna juga membutuhkan umpan dalam pengoperasiannya. Umpan tersebut umumnya dari jenis ikan rucah yang ditangkap sendiri atau dibeli dari nelayan lainnya. Menurut Rahmi et al. (2013), penangkapan ikan rucah oleh nelayan handline di perairan D.I. Yogyakarta biasanya menggunakan gillnet yang disiapkan khusus di kapal handline. Akan tetapi, tidak sedikit yang dibeli bila harganya cukup murah. Yuniarta et al. (2017) dan Partosuwirjo et al. (2008) menyatakan bahwa nelayan pantai Selatan Jawa termasuk di perairan D.I. Yogyakarta biasanya membeli umpan pada musim puncak untuk mengefektifkan waktu penangkapan. Tabel 4 menyajikan hasil analisis kelayakan investasi handline tuna D.I. Yogyakarta.

Berdasarkan Tabel 4, handline tuna mempunyai nilai NPV yang baik, yaitu mencapai Rp. 425.121.064. Nilai NPV ini merepresentasikan keuntungan bersih yang dapat diterima selama masa operasi handline tuna. Mustaruddin et al. (2014) dan Prabowo et al. (2013) menyatakan bahwa nilai NPV tersebut

Tabel 2 Kebutuhan investasi handline tuna

\begin{tabular}{lr}
\hline \multicolumn{1}{c}{ Kebutuhan investasi } & \multicolumn{1}{c}{ Nilai (Rp) } \\
\hline Kapal motor & 155.000 .000 \\
Handline (5 set) & 8.750 .000 \\
Gillnet (penangkap umpan) & 20.000 .000 \\
Mesin induk 30 PK (Yanmar) & 40.000 .000 \\
Mesin tambahan (Giandong) & 14.000 .000 \\
GPS & 2.000 .000 \\
Radio HT & 2.500 .000 \\
Lampu merkuri (6 buah) & 6.000 .000 \\
Cooler box besar/wadah & 950.000 \\
Tangki/drum air (3 drum) & 750.000 \\
\hline Jumlah & 249.950 .000 \\
\hline
\end{tabular}

Tabel 3 Kebutuhan operasional handline tuna

\begin{tabular}{lr}
\hline \multicolumn{1}{c}{ Kebutuhan operasional } & Nilai (Rp/tahun) \\
\hline Gas elpiji $3 \mathrm{~kg}$ & 3.900 .000 \\
Solar & 88.920 .000 \\
Oli & 3.168 .750 \\
Umpan & 9.055 .000 \\
Es balok & 27.800 .000 \\
Garam & 8.190 .000 \\
Air tawar & 2.106 .000 \\
Ransum & 25.350 .000 \\
\hline Jumlah & 168.489 .750 \\
\hline
\end{tabular}

Tabel 4 Hasil analisis kelayakan investasi handline tuna

\begin{tabular}{lcrr}
\hline Parameter & Standar & IRR & Keterangan \\
\hline NPV & $>0$ & Rp 425.121.064 & Layak \\
IRR & $>12 \%$ & $36,49 \%$ & Layak \\
ROI & $>1$ & 9,36 & Layak \\
B/C ratio & $>1$ & 1,22 & Layak \\
\hline
\end{tabular}

Keterangan: $\mathrm{NPV}=$ net present value; $\mathrm{IRR}=$ internal rate return; $\mathrm{ROI}=$ return of investment; $\mathrm{B} / \mathrm{C}$ ratio = benefit cost ratio 
diperhitungkan dari nilai yang berlaku (present value) dan sudah memasukkan pengaruh suku bunga kredit dalam perhitungannya. Nilai IRR handline tuna juga termasuk baik, yaitu $36,49 \%$. Hal ini menunjukkan bahwa menginvestasikan uang pada handline tuna dapat menghasilkan rasio keuntungan yang sangat layak $(36,49)$, meskipun uang tersebut berasal dari $p$ injaman bank dan lainnya. Hal ini karena rasio keuntungan tersebut dapat dengan mudah menutupi bunga pinjaman kredit (12\%/tahun). Batista et al. (2015) dan Prabowo et al. (2013) menyatakan bahwa di samping menguntungkan, nilai keuntungan investasi harus cukup besar supaya dapat menutupi semua pospos pembiayaan, terutama bunga kredit/pinjaman yang biasanya cukup besar. Hasil survei menunjukkan bahwa sekitar $71 \%$ nelayan di D.I Yogyakarta mengandalkan pinjaman untuk biaya operasional melaut. Hal ini dominan karena hasil tangkapan ikan yang sifatnya musiman (tidak kontinyu) sehingga ada rentang waktu di mana nelayan tidak bekerja dan kehabisan modal.

Handline tuna yang dioperasikan nelayan di D.I. Yogyakarta juga mempunyai tingkat pengembalian investasi (ROI) yang tinggi, yaitu 9,36 . Hal ini dominan karena rasio keuntungan bersih usaha handline tuna yang cukup besar dan diyakini dapat menutupi biaya investasi (Rp249.950.000.00) yang digunakan. Bahkan biaya investasi tersebut dapat dikembalikan pada tahun-tahun awal handline tuna dioperasikan. Selama masa operasinya (8 tahun), pengembalian investasi handline tuna cukup untuk mengembangkan sembilan usaha sejenis $(\mathrm{ROI}=9,36)$. Mustaruddin et al. (2014) dan Rahmi et al. (2013) menyatakan bahwa tingkat pengembalian investasi menjadi pertimbangan utama investor dengan modal terbatas, sementara keinginan mengembangkan usahanya sangat tinggi. Handline tuna juga mempunyai $B / C$ ratio $>1$, yaitu 1,22 yang menunjukkan bahwa penerimaan selalu lebih besar daripada semua pembiayaan yang dikeluarkan untuk mendukung operasi handline tuna. $\mathrm{Hal}$ ini sangat baik karena usaha selalu dapat menghasilkan keuntungan dalam pengoperasiannya. Oleh karena parameter NPV, IRR, ROI, dan B/C ratio dapat dipenuhi dengan baik maka dari segi investasi, usaha handline tuna prospektif untuk dikembangkan di D.I. Yogyakarta termasuk dengan mengundang investor luar. $\mathrm{Di}$ samping regulasi, kinerja investasi menjadi pertimbangan penting bagi investor untuk berinvestasi pada suatu bisnis perikanan. Hal ini karena kinerja investasi merupakan representasi dari karakter suatu usaha/bisnis dan dapat ditingkatkan bila manajemen usaha bekerja optimal (Merkel \& Madsen 2019 dan Lubis et al. 2012).

\section{KESIMPULAN}

Potensi sumber daya ikan tuna di perairan D.I. Yogyakarta mencapai 628,53 ton/tahun, sedangkan produksi rata-rata 427,32 ton/tahun (tingkat pemanfaatan $67,99 \%$ ) sehingga masih prospektif untuk dikembangkan. Fishing ground potensial tuna yang mendukung operasi handline umumnya tersebar di perairan Kabupaten Bantul hingga perairan perbatasan barat Kabupaten Gunung Kidul, serta di perairan timur Kabupaten Gunung Kidul. Pengumpulan ikan tuna di perairan Kabupaten Bantul perairan barat Kabupaten Gunung Kidul diduga terjadi pada bulan April, September, dan Oktober, sedangkan di perairan timur Kabupaten Gunung Kidul pada bulan Mei, Juni, dan Agustus. Handline tuna juga prospektif untuk dikembangkan investasinya di D.I. Yogyakarta. Nilai $\mathrm{NPV}, \mathrm{IRR}, \mathrm{ROI}$, dan $\mathrm{B} / \mathrm{C}$ ratio handline tuna sangat baik, yaitu masing-masing $\mathrm{Rp} 425.121 .064,36,49 \%$, 9,36 , dan 1,22 .

\section{DAFTAR PUSTAKA}

[BAPPEDA] Badan Pemerintahan Daerah. 2019. Aplikasi Dataku Daerah Istimewa Yogyakarta. [Internet]. [diakses 2019 Feb 8]. Tersedia pada: http://bappeda. jogjaprov.go.id/dataku/data_dasar/ cetak/132-perikanan-tangkap-laut

Batista MI, Horta e Costa B, Gonçalves L, Henriques M, Erzini K, Caselle JE, Gonçalves EJ, Cabral HN. 2015. Assessment of catches, landings and fishing effort as useful tools for MPA management. Journal of Fisheries Research. 172(1): 197-208. https:// doi.org/10.1016/j.fishres.2015.07.020.

Coelho R, Fernandez-Carvalho J, Santos MN. 2015. Habitat use and diel vertical migration of bigeye thresher shark: Overlap with pelagic longline fishing gear. Journal of Marine Environmental Research. 112(2): 91-99. https://doi.org/10.1016/j.marenvres. 2015. 10.009 .

[DKP] Dinas Kelautan dan Perikanan Daerah Istimewa Yogyakarta. 2018. Laporan Kinerja Sektor Perikanan dan Kelautan Daerah Istimewa Yogyakarta. Dinas Kelautan dan Perikanan Daerah Istimewa Yogyakarta. Yogyakarta (ID).

Doddema M, Spaargaren G, Wiryawan B, Busha SR. 2018. Fisher responses to private monitoring interventions in an Indonesian tuna handline fishery. Fisheries Research. 208(1): 49-57. https:// doi.org/10.1016/j.fishres.2018.07.009

Gephart GA, Deutsch L, Pace MM, Troellb M, Seekellde DA. 2017. Shocks to fish production: Identification, trends, and consequences. Global Environmental Change. 42(1): 24-32. https://doi.or g/10.1016/j.gloenvcha.2016.11.003

Hanley ND, Spash C. 1993. Cost-Benefic Analysis and the Environment. Cheltenham: Edward Elgar.

Keputusan Menteri Kelautan dan Perikanan Republik Indonesia Nomor 107/Kepmen-KP/2015 tentang Rencana Pengelolaan Perikanan Tuna, Cakalang dan Tongkol.

Lubis E, Pane AB, Muninggar R, Hamzah A. 2012. Besaran Kerugian Nelayan dalam Pemasaran Hasil 
Tangkapan: Kasus Pelabuhan Perikanan Nusantara Palabuhanratu. Maspari Journal. 4(2): 159-167.

Jalali MA, Lerodiaconou D, Monk J, Gorfine H, Rattray A. 2015. Predictive mapping of abalone fishing grounds using remotely-sensed LiDAR and commercial catch data. Journal of Fisheries Research.169(1): 26-36.

Jaquemet S, Potier M, Menard F. 2010. Do drifting and anchored Fish Aggregating Devices (FADs) similarly influence tuna feeding habits? A case study from the Western Indian Ocean. Fisheries Research. 107(1-3): 283-290. https://doi.org/10.10 16 /j.fishres.2010.11.011

Macdonald P, Laurenson CH, Johnson A, Tait L. 2009. A comparison of catch rates of artificial lures from an automated handline fishery at Shetland, UK. Fisheries Research. 95(2): 379-385. https//doi.org/ 10.1016/j.fishres.2008.10.003

Macusi ED, Babaran RP, van Zwieten PAM. 2015. Strategies and tactics of tuna fishers in the payao (anchored FAD) fishery from general Santos city, Philippines. Marine Policy. 62(1): 63-73. https,//doi. -org/10.1016/j.marpol.2015. 08.020

Mayes TR, Shank TM. 2006. Financial Analysis with Microsoft Excel 4th Edition. Pub, Nashville (US): South-Western College.

Merkel A, Madsen SKS. 2019. Lessons from port sector regulatory reforms in Denmark: An analysis of port governance and institutional structure outcomes. Transport Policy. 78(1): 31-41.

Mustaruddin, Asnil. 2020. Penentuan Wilayah Basis untuk Pengembangan Usaha Perikanan Tangkap Ramah Lingkungan di Perairan Pulau Salahnama dan Pulau Pandang. Jurnal IImu Pertanian Indonesia. 25(2): 253-260. http://dx.doi.org/ 10.18 343/jipi.25.2.253

Mustaruddin, Wiyono ES, Khotib M, Asnil, Bahri S. 2018. Pola pencemaran lokasi penangkapan dan ikan hasil tangkapan akibat berkembangnya aktivitas ekonomi di sekitar Danau Maninjau. Jurnal Pengelolaan Sumber daya Alam dan Lingkungan. 8(2): 134-142. https://doi.org/10.29244/jpsl.8.2.13 4-142.

Mustaruddin, Baskoro MS, Supriatna A. 2014. Strategi Pengembangan Perikanan Cakalang yang Bersinergi dengan Faktor Lingkungan dan Sosial Ekonomi di Ternate: Studi Kasus Penangkapan Ikan Menggunakan Huhate. Jurnal IImu Pertanian dan Perikanan. 3(1): 1-9.

Nurani TW, Wahyuningruma PI, Wisudo SH, Gigentika S, Arhatin RE. 2018. Model designs of Indonesian tuna fishery management in the Indian Ocean (FMA
573) using soft system methodology approach. The Egyptian Journal of Aquatic Research. 44(2): 139-144. https://doi.org/10.1016/j.ejar.2018.06.005

Partosuwirjo M, Haluan J, Baskoro MS, Soemokaryo S. 2008. Model Pengembangan Usaha Perikanan Tangkap di Daerah Istimewa Yogyakarta. Jurnal Manajemen dan Agribisnis. 5(1): 23-32.

Punzon A, Villamor B, Preciado I. 2004. Analysis of the handline fishery targeting mackerel (Scomber scombrus, L.) in the North of Spain (ICES Division VIIlbc). Fisheries Research. 69(2): 189-204. https:// doi.org/10.1016/j.fishres.2004.05.002

Prabowo, Wiyono ES, Haluan J, Iskandar BH. 2013. Kinerja pembiayaan perikanan skala kecil di Kota Tegal, Provinsi Jawa Tengah. Marine Fisheries. 4(1): 1-9.

Rahmi TA, Nurani TW, Wahyuningrum PI. 2013. Usaha Perikanan Tangkap Skala Kecil di Sadeng, Provinsi Daerah Istimewa Yogyakarta. Jurnal Amanisal. 2(2): 40-45.

Riandani PA, Bambang AN, Ismail. 2015. Tingkat Pemanfaatan dan Optimalisasi Fasilitas Dasar dan Fungsional di Pelabuhan Perikanan Pantai Sadeng Gunung Kidul Dalam Menunjang Pengembangan Perikanan Tangkap. Journal of Fisheries Resources Utilization Management and Technology. 4(3): 10-20.

Sanders MJ. 1999. Fishery performance and the value of future entitlements under quota management: $A$ case study of a handline fishery in the southwest Indian Ocean. Fisheries Research. 18(3-4): 219-229. https://doi.org/10.1016/01657836(93)901 54-Y.

Simbolon D, Irnawati R, Sitanggang LP, Ernaningsih D, Tadjuddah M, Manopo VEN, Karnan, Mohammad. 2009. Pembentukan Daerah Penangkapan Ikan. Bogor (ID): Departemen Pemanfaatan Sumber daya Perikanan FPIK IPB.

Sumaila UR, Bellmann C, Tipping A. 2016. Fishing for the future: An overview of challenges and opportunities. Journal of Marine Policy. 69(1): 173-180. https://doi.org/10.1016/j.marpol.2016.01. 003.

Undang-Undang No. 45 Tahun 2009 Tentang Perubahan Atas Undang-Undang Nomor 31 Tahun 2004. Tentang Perikanan

Yuniarta S, van Zwieten PAM, Groeneveld RA, Wisudo $\mathrm{SH}$, van lerland EC. 2017. Uncertainty in catch and effort data of small and medium-scale tuna fisheries in Indonesia: Sources, operational causes and magnitude. Fisheries Research. 193(1): 173-183. 